subgenomic particles associated with measles virus infections. Dr. S. J. Martin will direct the work.

\section{Royal College of Obstetricians and Gynaecologists}

At a meeting of the council of the college held on 27 July the following officers were elected for the year 1974-5: president, Sir Stanley Clayton (re-elected); senior vicepresident, Dame Josephine Barnes; junior vice-president, Dr. Robin Murdoch; honorary treasurer, Mr. G. D. Pinker (re-elected); honorary secretary, Mr. R. T. Booth (reelected).

\section{People in the News}

Dr. W. Charles Cockburn, at one time director of the Epidemiological Research Laboratory of the M.R.C., has been appointed director, Division of Communicable Diseases, World Health Organization.

Lord Porritt has been elected chairman of the Arthritis and Rheumatism Council.

\section{COMING EVENTS}

Association for the Study of Medical Education.- (1) Annual general and scientific meetings, 10-11 September, Edinburgh University; (2) Education," 9-10 September, Edinburgh, organized by Association for Medical Education in Europe. Details of both items from the administrator, (Tel. 0382 26801.)

"Psychosexual Problems."-Congress, 11-13 September, Bradford, organized by B.M.A. Board of Science and Education and Bradford University. of Science and Education and Bradford University. Details from Dr. H. B. Milne, Postgraduate School
of Studies in Medical and Surgical Sciences, Bradford University, Bradford, Yorks BD7 1DP. (Tel. Bradford 33466.)

10th European Conference on Psychosomatic Research. - 15-20 September, Edinburgh University. Details from the conference secretariat, university department of psychiatry, Royal Edinburgh Hospital, Morningside Park, Edinburgh EH10 5HF. (Tel. 031-447 2011, extn. 280.)

"Total Knee Replacement."-Symposium, 1618 September, London S.W.1, by Institution of Mechanical Engineers and British Orthopaedic Association. Application to Institution of Mech-
anical Engineers, 1 Birdcage Walk, London SW $1 \mathrm{H}$ 9JJ. (Tel. 01-839 1211.)

"Medical Use of Hospital Grounds."-Day conference, 26 September, London W.1, organized by Bath University in association with King's Fund Centre. Fee $£ 2 \cdot 50$. Applications, before 4 September, to the assistant director, King's Fund Centre, 24 Nutford Place, London W1H 6AN. (Tel. 24 Nutford

International Society for Prosthetics and Orthotics.-World congress, 8-12 October 1974 Montreaux. Details from the secretary-general, Dr. R. F. Baumgartner, I.S.P.O. World congress,
P.O. Box, CH-8126 Zumi:on/Zurich, Switzerland. 4th Congress of the International Federation of Manual Medicine.-9-12 October 1974, Prague. Details from the secretariat of the congress, Sokolska 31, Praha 2, Czechoslovakia.

Bateman Centre for Postgraduate Medical Studies.-Copies and details of the 1974-5 programme, September-June, are obtainable from the dale, Lancs, OL12 9QB. (Tel. Littleborough 78294, extn. 253.)

Forest Group Hospitals Medical Education and Research Trust.-Copies and details of the programme, September-December, are obtainable Whipps Cross Hospital, London E.11. (Tel Whipps Cross Hospita
01-539 5522, extn. 310.)

\section{UNIVERSITIES AND COLLEGES}

ROYAL COLLEGE OF PHYSICIANS OF

At a quarterly meeting of the college held on 25 July, with the president, Sir Cyril Clarke, F.R.S. senior censor and senior vice-president.
Dr. C. A. Young was elected as second censor. Dr. C. A. Young was elected as second censor.
Dr. R. D. Tonkin was elected as third censor. Dr. J. D. N. Nabarro was elected as fourth censor. Dr. J. M. Ledingham, Dr. C. C. Booth Dr. N. D. Compston was re-elected treasurer. Sir Kenneth Robson was re-elected registrar. Dr. D. A. Pyke was elected registrar-elect. Dr. C. E. Newman was re-elected Harveian Dr. P. A. J. Ball was re-elected assistant registrar. Dame Albertine Winner was re-elected Linacre
Fellow. The following appointments were approved: Dame Albertine Winner as college representative on the governing body of the British Postgraduate The president and Dr. P. A. Emercon as college nominees on the Joint Consultants Committee. 1974 to Dr. C. Gopalan was announced.
The award of the Oliver Sharpey prize to Dr. W The award of the Oliver Sharpey prize to Dr. W

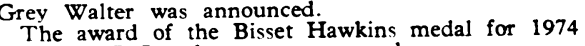
to Dr. P. J. Lawther was announced. Dr. E. H. O. Parry and Dr. G. C Cook were
present to recieve jointly the Frederick Murgatroyd prize. following were elected and admitted as members of the college: R. D. Hoare, V. R. McCready, J. G. Widdicombe.

ROYAL COLLEGE OF OBSTETRICIANS AND GYNAECOLOGISTS

At meetings of the council of the college held on 26 and 27 July, with the President, Sir Stanlev Clavton, in the the college

Tinuola A. Abiola. A. Abu Sharar, I. S. Ahluwalia, A. B. Alailv, S. A. Almohdzar, F. I. Al-Shamma, Luan T. Ang, Jasentuliyana C. Arvsingha, C. R. Banerjee, Thikra Bashir, A. R. Basu, Halima Begum, Lakshmi Bharagava, Dharani Bora, Pranab K. Chakrabarti, Asim Debrav, R. G. K. De Mel, Indira Dhupelia, M. F. E. Diejomaoh, Premathilake B. Doloswala, R. A. Emens, Maria D. Falzon, O. A. Finnih, J. George, A. S. M. A. Gerais, Sarat, K. Ghosh, I. D. Goil, K. J. Gupta, A. J. Hamilton, M. A. O. Hamza, Olwen Harries, N. M. Hidavet, P. Jackson. *C. P. Jardine-Brown,
H. Javey, A. J. Jones, J. B. Jones, H. C. M. Kairuki, H. Javey, A. J. Jones, J. B. Jones, H. C. M. Kairuki,
D. Kalita, F. A. Kamal, A. K. Kanwar, E. Kaplan,
J. C. Kelly, Radha V. Krishnan, W. K. Lee, K. F. Luk, J. C. Kelly, Radha V. Krishnan, W. K. Lee, K. F. Luk, N. E. MacLean, Margaret B. McNay, B. S. Mangat, M. R. Mayall, B. M. Mulholland, A. N. M. Mustafa, Vijavamala B. Patil, Pallanyvelu Pillay, S. Ouist, Sanath R. Ratnapala, C. Riris, I. D. Rollev, I. G. Rowlands,
Susheela H. Salis, A. E. Schaetzing, M. A. M. Shahata, Susheela H. Salis, A. E. Schaetzing, M. A. M. Shahata, Sinha, Debi P. Sinha, Rangila Sinha, Mariorie E. V. Taam, A. A. Templeton, Iune Thapa Thein New Nwe, G.P. Theophilus, C. A. Thornton, B. I. Trudinger, G. R. Uma Bai, Madathilkatt I. Umadevi, C. C. Validen, J. A. Wallace, Susantha P. Weerasinghe, T. Wheeler, *Awarded regional councils' gold medal.

\section{APPOINTMENTS}

Northern Regional Health Authority.-Dr. J. L Richards (consultant. histopathology, Cleveland A.H.A.); Dr. O. El F. M. Fadl (consultant, mental illness, Sunderland A.H.A.); Mr. M. P. Holden (consultant, cardiothoracic surgery, Regrth-west Durham district. Durham area); Dr. A. on North-west Durham district. Durham area); Dr. A trict, Durham area); Mr. M. G. Whittaker (consultant, general surgery, Darlington district. Durham A.H.A.
joint appointment with Yorkshire R.H.A. in Northallerton district of North Yorkshire A.H.A.); Mr M. Flynn (consultant, orthopaedic surgery, Hartle-
pool district, Cleveland area); Dr. I. D. L. Brewis pool district, Cleveland area); Dr. I. D. Lumbria district, Cumbria area); Dr. Ann M. Lewis (oonsultan geriatric medicine, South Tees district, Cleveland
area); Dr. D. C. Thrush (consultant, neurology,
Cleveland A.H.A.); Mr. J. W. Foulds (consultant, obstetrics and gynaecology, South-west Durham district, Durham area); Mr. J. E. R. Lart (con
sultant obstetrics and gynaecology, Darlingtoon district, Durham A.H.A., joint appointment with Yorkshire R.H.A. in Northallerton district of North Yorkshire A.H.A.); Dr. B. G. Watson (consultant anaesthetics (cardiothoracic), Regional Service based
on North-west Durham district, Durham area);
Dr. Barbara A. Robertshaw (consultant, mental handicap, Durham A.H.A.); Dr. G. H. Evans (consultant, general medicine, North Tyneside A. Cameron (consultant, otolaryngology, joint appointment with Newcastle A.H.A. (T) and NorthNorth-western Regional Health Authority.Mr. J. D. Wright (consultant obstetrician and gynaecologist. Preston and Chorley group); Miss E. P. Leaver (consultant obstetrician and gynaecologist, South Cheshire group); Dr. C. J. Pemberton (consultant anaesthetist, Stockport and Buxton group);
Dr. S. M. Berger (consultant anaesthetist, Northeast Manchester and Booth Hall groups); Dr. E. T L. Davies (consultant physician, East Cheshire group); Dr. B. G. Swales (consultant anaesthetist, Dr. P. B. Lees (consultant radiologist, Stockport Dr. P. B. Lees (consultant radiologist, Stockport physician, Wythenshawe and North Cheshire group); Dr. C. de S. Mutucumarana (consultant physician in geriatric medicine, Bury and Rossendale groups) Dr. W. J. Charles (consultant psychiatrist. Black-
pool district of Lancashire A.H.A.); Dr. B. N. Mallik. Dr. S. A. Rehman (consultant physicians in geriatric medicine, Blackburn district of Lancashir with special interest in chest diseases, Stockport A.H.A.); Dr. W. G. T. Annan (consultant physician in geriatric medicine. Blackpool district of Lancasurgeon, Cumbria and Lancashire A.H.A.'s).

South-Western Regional Health Authority.-Dr. T. R. Brown (consultant radiologist, Somerset area) Dr. J. F. Searle (consultant anaesthetist. Devon area, Exeter); Dr. D. C. L. Savage (consultant paediatrician, Avon area); Dr. C. S. Fowergency, Gloucestershire area); Dr. Angela M. and emergency, Gloucestershire area); Dr. Ancelil area); Dr. P. J. A. Willems (consultant psvchiatrist with a special interest in alcoholism, Avon area); Dr. G. Pell (consultant dental surgeon, Avon area); Mr. T. Thomsitt consultant ophthalmologist, Devon area, Exeter): Dr. A. S. S. Rowe (consultant in geriatric medicine, Devon area. Plvmouth); Dr. K. E. Schmidt (consultant psychiatrist, Somerset area); Dr. P. V. Hunt (consultant psvchiatrist, Somerset area): Dr. sultant paediatrician, Devon area): Dr. R. J. Fltringham (consultant anaesthetist, Gloucestershire area); Miss D. Magauran (consultant ophthalmologist, Gloucestershire area): Dr. A. P. C. H. Roome (consultant microbiologist, Gloucestershire area); Dr. M. Rarry (consultant in general medicine, Somerset area); Somerset area).

\section{Corrections}

Working Party on Rehabilitation Services in South Wales

Dr. R. B. Body, a member of the working party, was inadvertently referred to as Chief Medical Officer, British Steel Corporation (27 July, p. 268). His correct title is Chief Medical Officer, Por

Annual Representative Meeting-Kingstonupon Hull, 1974

In the report of the proceedings of the Annual Representative Meeting under "Finance" (3 August, p. 360) the paragraph on taxation should have read: "Taxation during the year had increased by $£ 44,000$ owing to the increases in taxable
income from rents and publishing and because the tax rate rose from $40 \%$ to $49 \%$.'

\section{Notice to Authors}

When original articles and letters for publication are not submitted exclusively to the British Medical fournal this must be stated. Accepted articles may subsequently be selected for publication in the North American monthly edition.

Correspondence on editorial business should be addressed to the Editor, British Medical fournal, B.M.A. House, Tavistock Square, London WC1H 9JR. Telephone: 01-387 4499. Telegrams: Aitiology, London, W.C.1.

Authors wanting reprints of their articles should notify the Publishing Manager, B.M.A. House, Tavistock Square, WC1H 9JR, on receipt of proofs.

\section{(C) British Medical Journal 1974}

All Rights Reserved. No part of this publication may be reproduced, stored in a retrieval system or transmitted, in any form or by any means, electronic, mechanical, photocopying, recording or otherwise, without the prior permission of the British Medical fournal. 